\title{
TURBULENS PERDÜLETES LÁNG AKUSZTIKAI DIAGNOSZTIKÁJA
}

\section{ACOUSTIC DIAGNOSTICS OF A SWIRLING TURBULENT FLAME}

\author{
Novotni Gergely István ${ }^{1}$, Józsa Viktor ${ }^{2}$ \\ BME Gépészmérnöki Kar, Energetikai Gépek és Rendszerek Tanszék, 1111 Buda- \\ pest, Müegyetem rkp. 3., Magyarország; Telefon: +36-1-463-2596; \\ Inovigeri93@gmail.com, jozsa@energia.bme.hu
}

\begin{abstract}
In order to fulfill the continuously stringent emission standards, lean premixed flames are used. However, such an operation results in an operation near the lean blowout limit which can be diagnosed by acoustic devices. During the investigation, a $15 \mathrm{~kW}$ lean premixing prevaporizing-type swirl burner was used. Diesel oil was utilized as fuel which was atomized by an airblast atomizer. Depending on the swirl number, straight, V-shaped, and in the transition regime both can be observed. Therefore, a bistable region separates the two regimes in which the equivalent sound pressure level was investigated and its relation to the flame shapes.
\end{abstract}

Keywords: flame stability, swirl number, turbulent flame, liquid fuel combustion, acoustics

\section{Összefoglalás}

A folyamatosan szigorodó emissziós normák teljesítése érdekében szegény keverékü, előkevert lángokat alkalmazunk. Viszont az ilyen üzem a lánglefúvási stabilitási határhoz igen közel esik, melyet akusztikai eszközökkel diagnosztizálhatunk. A vizsgálathoz egy $15 \mathrm{~kW}$-os szegény keverékü, előkeveréses, előpárologtató rendszerű perdületes égőt alkalmaztunk. A tüzelőanyag dízelolaj volt, amit egy levegő segédközeges porlasztóval porlasztottunk. A perdület-paraméter függvényében egyenes, Valakú, illetve az átmenet során mindkét lángalak megfigyelhető, tehát egy bistabil régió választja el a két tartományt. Ezekben vizsgáltuk az egyenértékü hangnyomásszintet és ennek kapcsolatát a lángalakokkal.

Kulcsszavak: lángstabilitás, perdület-paraméter, turbulens láng, folyadéktüzelés, akusztika

\section{Bevezetés}

A folyamatosan szigorodó emissziós normák miatt a tüzeléstechnikában a szegény keverékü tüzelés dominál, mivel így lehet tartani az elöírt nitrogénoxid koncentrációt. Azonban minden határon túl nem szegényíthető a keverék, hiszen az égés mindössze a 2-es légfelesleg-tényezöig tartható fent [1]. A lánglefúvási határhoz közeledve egyre csökkenő frekvenciájú oszcilláció figyelhető meg a hőfelszabadulás- és a nyomásjelben is [2]. Tehát a lángakusztikai tervezés napjainkban igen kritikussá vált. Korábban a széles körben alkalmazott diffúz lángok esetében ilyen probléma nem merült fel, így a rendelkezésre álló irodalom igen szükös. A lángakusztikai jelenségek ismeretében viszont már megfelelő szabályzó- és on-line felügyeleti 
rendszerek telepíthetök a müködés kézben tartása érdekében.

A tüzelöberendezésekben alapvetően két oka van a zaj keletkezésének. Az egyik a turbulencia, ami eleve spektrális jelenség, míg a másik a hőfelszabadulás, ami a turbulens áramképpel való interakciója miatt szintén széles frekvenciatartománnyal jellemezhető [3]. Az égési zaj fontos zajforrás többek között ipari kemencékben és tüzelöberendezésekben, fáklyázásnál, repülőgép hajtómüveknél, gázturbináknál és diesel motoroknál [4].

Perdületes áramlások, így égések összehasonlítására a perdület-paramétert alkalmazzuk, melynek számítása (1) szerint történik [5]:

$$
S=\frac{G_{\varphi}}{G_{\chi} \cdot R^{\prime}}
$$

ahol $G_{x}$ a közeg perdületének a tengelyirányú komponense, $G_{\varphi}$ az axiális irányú impulzuserő és $R$ az áramcső sugara. Ennek számértéke alapján beszélhetünk gyengén perdületes $(S<0,6)$, illetve erösen perdületes áramlásokról $(S>0,6)$.

A mérésünk során alapvetően három lángstabilitási fázist különböztetünk meg, melyek perdület-paramétertől függenek. A gyengén perdületes áramlások esetén egyenes lángalakról beszélünk, míg erősen perdületes áramlásoknál a precesszáló örvénymag leszakad és egy külső-, valamint egy belső recirkulációs zóna (ORZ és IRZ) alakul ki [5], ami az 1. ábrán látható. Ekkor a láng $\mathrm{V}$ alakot vesz fel, mivel az intenzív égés a két zóna határán történik. Az egyenes és a $\mathrm{V}$ alakú lángok közt az átmenet egy bistabil régióval jellemezhető, melyben a lángalakok változása kaotikus, azonban átlagosan az a lángalak figyelhető meg tovább, amelyik stabil formához közelebb vagyunk.

Jelen cikkben az említett lángalakok egyenértékü hangnyomásszintre kifejtett hatását vizsgáljuk, mely eredmények direkt módon használhatóak a tüzeléstechnikai tervezéshez.

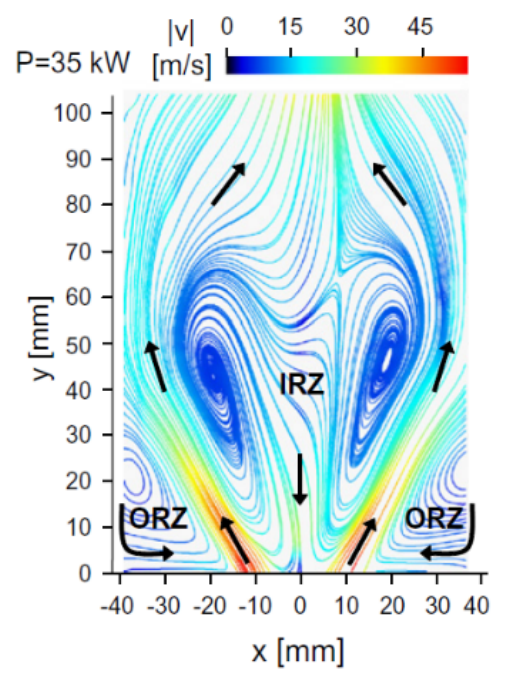

1. ábra. Áramlási kép V alakú láng esetén [6].

\section{A mérés menete}

A méréseket egy szegény keverékkel üzemelö, előkeveréses, előpárologtató rendszerü, perdületes égővel végeztük, melynek metszete a 2. ábrán látható. A tüzelőanyag szabványos dízelolaj (EN 590:2014) volt, melyet egy levegő segédközeges porlasztóval porlasztottunk. Itt a központi tüzelöanyag vezetékkel koncentrikusan lép be a nagysebességü porlasztólevegö, mely a folyadéksugarat cseppekre bontja. Az égéslevegő négy tisztán radiális kör keresztmetszetü és tizenöt $45^{\circ}$-os téglalap keresztmetszetü nyíláson keresztül lép be a keverőcsőbe [7]. Ez utóbbi nyílások felelősek a perdületes áramlás kialakulásáért.

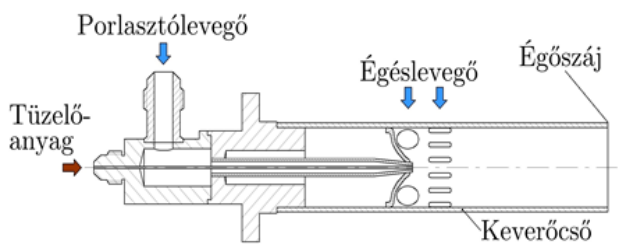

2. ábra. A mérés során használt égö metszete 
A láng stabilitásának növelése érdekében egy $30^{\circ}$-os félkúpszögü diffúzort illesztettünk az égő szájára. Az itt bemutatott eredmények esetében csak ezt a konfigurációt elemezzük. A lángstabilitás fentebb említett három fázisát a $\mathbf{3}$. ábra szemlélteti.
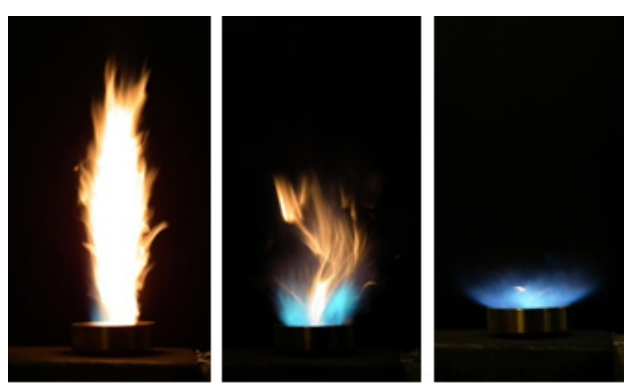

3. ábra. Balról jobbra: Egyenes, bistabil és stabil V alakú láng.

$\mathrm{Az}$ égéslevegőt $400^{\circ} \mathrm{C}$-ra melegítve juttattuk be a keveröcsőbe. Az égési zajt egy SVAN 971 típusú zaj analizátor segítségével mértük, melyet a lángtól $1 \mathrm{~m}$-re helyeztünk el oldalirányban. A mikrofon mintavételezési frekvenciája $12 \mathrm{kHz}$ volt. Az egyenértékü hangnyomásszint mellett a minimum, illetve maximum hangnyomásszintet is mértük. Spektrális szempontból $Z$ szürőt alkalmaztunk, mely egyformán súlyozza az összes frekvenciát.

A mérés során 0,75 bar állandó porlasztónyomás mellett fokozatosan növeltük az égéslevegő tömegáramát $11,91 \mathrm{~kg} / \mathrm{h}$-tól a láng lefúvásáig, $2,38 \mathrm{~kg} / \mathrm{h}$-s lépésközzel.

\section{Az eredmények értékelése}

A mérési sorozatból nyert adatok feldolgozásának és kiértékelésének gondolatmenete a lángalak hatásának vizsgálata a keletkező zajra. Az eredmények a 4. ábrán láthatóak. Mérési pontonként 30 másodperc mintavételezés logaritmikus átlagát tüntettük fel a minimum, maximum és egyenértékű $\mathrm{Z}$ hangnyomásszint szerint.

A vízszintes tengelyen a geometriai paraméterek és peremfeltételek segítségével meghatározott perdület-paraméter található. A piros jelölők a lángstabilitási határokat jelzik. 0,52-es perdület-paraméterig egyenes, 0,77-ig bistabil, e fölött pedig V alakú lángot tapasztaltunk.

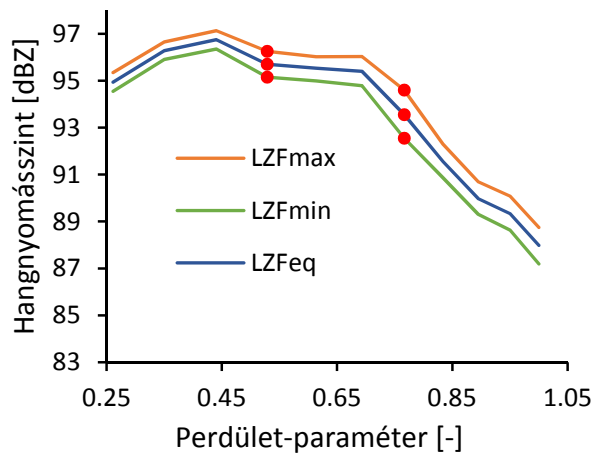

4. ábra. Hangnyomásszint a perdület-paraméter függvényében.

Az első szakasz elején enyhén emelkedik a hangnyomásszint, ami azzal magyarázható, hogy a perdület-paraméter növekedésével intenzívebbé válik a tüzelőanyag és a levegő keveredése, ami növekvő nyírófeszültséget eredményez a közegben, növekvő zajkibocsátást eredményezve. Az enyhe csökkenés, illetve stagnálás, ami a bistabil zóna közel végéig tart, a megfelelően homogén keverék kialakulása miatt tapasztalható. Mivel a bistabil zóna egy átmenet az egyenes és a V alakú láng között, ezért mivel utóbbi felé tartunk, ami jóval kevésbé zajos, látható egy letörés. A perdületparaméter növelése, ami esetünkben a légfelesleg-tényező növelését is jelenti, a szegényebb keverék felé haladva közel lineáris zajcsökkenést mutat, egészen a lángkialvásig. Érdemes megjegyezni, hogy a logaritmikus skálán a minimális és a maximális átlagos hangnyomásszint értékek közt közel $10 \mathrm{~dB}$ a különbség, ami igen jelentősnek mondható.

A 4. ábrán látható egy érdekes jelenség, miszerint a maximális és minimális görbék kissé távolodnak egymástól. Ezt emeli ki az 
5. ábra, tehát a maximális és a minimális súlyozatlan hangnyomásszintek különbségét láthatjuk.

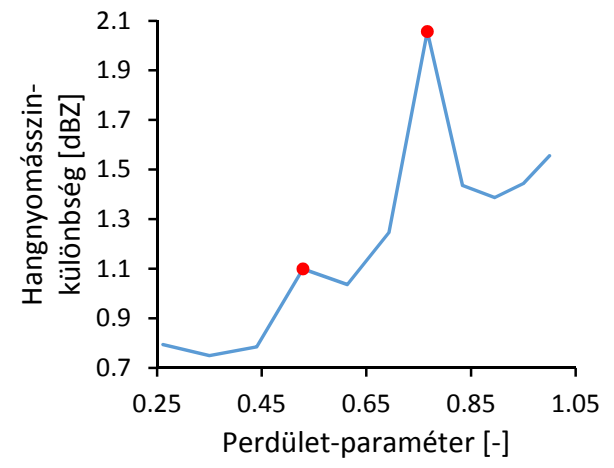

5. ábra. Hangnyomásszint különbség a perdületparaméter függvényében.

Itt a bistabil szakasz felé tartva nő a hangnyomásszint-különbség. A bistabil és a V alakú láng határán pedig egy csúcshoz érkezünk, ami a két lángalak közi gyors váltakozás eredményeképp alakul ki. A két lángalak közti váltás frekvenciája kb. 1$3 \mathrm{~Hz}$ között változott, így a gyors időátlagolás eredményeképp mért minimális és maximális hangnyomásszintekben már mind a két lángalak elég hosszan megjelenik. Így a zajosabb egyenes lángalak és a kevésbé zajos $\mathrm{V}$ alakú lángalak közti különbséget láthatjuk. Ezt a pontot elhagyva a $\mathrm{V}$ alakú láng hangnyomásszint-különbsége visszaesik, azonban a kiindulási pont közel duplája figyelhető meg itt. Ennek oka a keverék szegénységére vezethető vissza, mivel a keverék gyulladása kvázistacionáriussá válik.

\section{Következtetések}

A tanulmány során bemutattuk a perdületes turbulens láng megfigyelhető alakjait és ezeket akusztikai szempontból jellemeztük.

Az egyenes lángalak zaj szempontjából kevésbé érzékeny a perdület-paraméterre. Itt az üzemet egyenletes zajkibocsátás jel- lemzi, így a minimum és maximum hangnyomásszintek különbsége $1 \mathrm{~dB}$ körül mozgott. A bistabil zóna a hangnyomászszint-különbségek segítségével jól körülhatárolhatóvá vált. Ez az érték jelentősen visszaesett a tisztán $\mathrm{V}$ alakú láng esetén, míg az egyenértékü hangnyomásszint közel lineáris csökkenést mutatott, ami az egyenes lángalakhoz képest nem egészen $10 \mathrm{~dB}$ csökkenést jelentett.

\section{Köszönetnyilvánítás}

Ezúton szeretnénk megköszönni az Emberi Erőforrások Minisztériumának, hogy az ÚNKP-16-II. kódszámú, Új Nemzeti Kiválóság Program keretében támogatta a kutatást.

\section{Szakirodalmi hivatkozások}

[1] I. Glassman, R. Yetter: Combustion, 4. kiadás, Elsevier Academic Press, Burlington, 2008.

[2] Y. Huang, V. Yang: Dynamics and stability of lean-premixed swirlstabilized combustion, Prog. Energy Combust. Sci., vol. 35, no. 4, pp. 293364, 2009.

[3] W. C. Strahle: Combustion noise, Prog. Energy Combust. Sci., vol. 4, no. 3, pp. 157-176, 1978.

[4] A. H. Lefebvre, D. R. Ballal: Gas turbine combustion, 3. kiadás, $\mathrm{CRC}$ Press, Boca Raton, 2010.

[5] J. M. Beér, N. A. Chigier: Combustion aerodynamics. Robert E. Krieger publishing company, London, 1972.

[6] M. Stöhr, és mások: Experimental study of vortex-flame interaction in a gas turbine model combustor, Combust. Flame, vol. 159, no. 8, pp. 2636-2649, Aug. 2012.

[7] Gy. Hidegh, V. Józsa: Diffúzor alkalmazása perdületes égő lánglefúvási stabilitásának növelésére, Energiagazdálkodás, vol. 57, no. 3-4, pp. 17-20, 2016. 